\title{
RESEARCH
}

\section{History Politics and (Re)forming the Future: Visions of Democracy and the Category of the Utopian}

\author{
Anna Friberg \\ Department of Culture and Society (IKOS), Linköping University, SE \\ anna.friberg@liu.se
}

During the First World War, the legitimacy of established polities was challenged throughout Europe. Not only did the war affect the great powers; smaller nations that were not directly involved also experienced a resurgence of constitutional disputes. While these controversies have been analyzed as conceptual struggles, this article - inspired by Reinhart Koselleck's theory of historical times - suggests that they can also be understood as ideological struggles over temporalities. The article examines the Swedish parliamentary debates on further democratization after the introduction of universal suffrage. In this context, there were ideological struggles over how the historical development should be interpreted and differing visions of how the future should be shaped, resulting in varying understandings of what was required of the present. In the conclusion, the article addresses the Koselleckian categorization of temporal experience and argues that there is a need for another category, one that lies beyond calculable prognoses and predictions: the category of the utopian.

Keywords: democracy; horizons; Reinhart Koselleck; temporality; the utopian; time; utopia; visions of the future

\section{Introduction}

What can be done politically is to a large extent dependent upon what can be said and portrayed as doable. In politics, perceptions of time are crucial as they constitute prerequisites for political action, in the sense that understandings of the past influence how the present is understood and how the future can be envisaged. However, interpretations of the past are always affected by ideological factors and political interests. In this way, history politics and ideas about how to (re)form the future become deeply intertwined.

The aim of this article is to shed light on the complex relationship between time and politics; namely, how ideologically motivated narratives interrelate the past, present, and future, and the negotiation of contingency between these temporalities. Furthermore, the article explores how different modes of expectation can be helpful in understanding political actions from a temporal perspective. This is done with reference to the theoretical framework 
developed by the German historian Reinhart Koselleck. In the concluding section of the article - as a result of the empirical analysis - the article argues in favor of supplementing the Koselleckian categories of temporal experience with another: the utopian.

By examining political debates and analyzing these in relation to theoretical notions about time, the temporalization of politics - how time is conceptualized within politics - is highlighted. This empirical study focuses on parliamentary debates on political democracy in Sweden during the dynamic period following the First World War. The experiences of the war, together with the Russian February/March Revolution, led to a general questioning of the legitimacy of the established political order. This resulted in accelerating existing national calls for political reforms and hence enabled new visions of the future. In other words, the war experiences revived constitutional disputes and competing ideological conceptualizations that had been put aside during the war. To its contemporaries, this was a time characterized by vocal public demands for increased political influence. Temporally speaking, the war and revolution experiences became a transnational force that changed polities by separating the old world from the new and by opening new horizons by pushing the frontiers of political imagination (Eley 2002; Ihalainen 2017; Ihalainen \& Kinnunen 2019).

\section{Time, Language, and Politics}

This article is inspired by Koselleck's work on the connection between language and temporal experience; more precisely, how political concepts interrelate and provide experiences of time. Besides the project of designing a dictionary of the history and development of socio-political concepts during the late 18th and early 19th centuries - die Geschichtliche Grundbegriffe - for which he is perhaps best known, Koselleck was also devoted to developing a theory of historical times. Inspired by Martin Heidegger, Koselleck developed the notion of Being as a temporal phenomenon, unfolding in the interaction between past, present, and future. However, unlike Heidegger, Koselleck's theory focused on social temporality rather than individual. In line with this, the present should not be understood as a simple notion between a linear past and future, but rather as something that is created interpersonally through language. In terms of political concepts, this means that earlier usages limit their present usage. Thus, concepts not only incorporate experiences but also anticipate them, in the sense that future events are arranged into the language discourse of the present (Koselleck 2004; Olsen 2012).

The period after the First World War was to a great extent characterized by ideas of progress and change. After the horrifying experiences of the war, the general focus turned increasingly from the past to the future, and issues such as how democratic ideals - which appeared to be making international progress - could be realized, further permeated political debates. On a general level, history was understood as a continuous movement toward something better. Hence, the experience of history was a mixture of optimism and certainty (Eley 2002; Ihalainen 2017; Kloppenberg 1986). Albeit referring to the late 18th century, the phenomenon of a temporal shift in focus toward an increased interest in the future was expressed by Koselleck in terms of a changing relationship between the space of experience and the horizon of expectation, where the latter became increasingly important; the categories drifted apart. Koselleck $(2004,261)$ defined the concept of horizon by stating that 'The horizon is that line behind which a new space of experience will open, but which cannot be seen. The legibility of the future, despite possible prognoses confronts an absolute limit, for it cannot be experienced.' According to Koselleck, horizons represent temporal extensions from the present while at the same time marking out specific borders to these extensions. Moreover, because the past and the future never fully meet, expectations cannot be reduced to experiences. 
Thus, the future seems uncertain, but it also becomes plannable. Since the future is nonexistent, it is open to human agency and hence negotiated.

Within politics, time constitutes a central element since politics, at least ideally, deals with how the present should be managed and how the future can be shaped. Language plays an important role because political possibilities are dependent upon what can be said and depicted as doable. As Frank Ankersmit $(2002,117)$ has stated, 'the politician must possess the aesthetic talent of being able to represent political reality in new and original ways.' Political actors describe scenarios for the future as more or less probable, which means that different horizons are established. These horizons are created linguistically, through the usage of timelayered concepts. Likewise, experiences and expectations can be understood as something that political actors construct through rhetorical redescriptions. This means that temporal issues are, just like political concepts, subject to political conflict and contestation.

In this article, time will be treated as a heuristic lens, as an analytical tool, rather than as an empirical concept of the sources. Democracy will henceforth refer to the process of extending public possibilities for political participation. The focus of attention is on how future democracy was envisioned by representatives of the competing political groups in post-war Sweden. ${ }^{1}$ The study follows three debates that are representative of the political debate concerning matters of future democracy: a unicameral parliamentary system, the introduction of referenda, and a republican form of state.

\section{The Temporality of Democracy}

In Sweden, the franchise reform of 1919 - which in many ways was catalyzed by the fall of the German monarchy in the fall of 1918 - meant that all adult men and women were given the right to vote in parliamentary elections. ${ }^{2}$ In traditional history research, the introduction of universal suffrage has been described as the end of the democratization process in Sweden (e.g. Alexius 1997; Hadenius 1966; Olsson 2000). Naturally, such exact datings are a matter of hindsight perspective and are therefore not always reliable if the ideas and concepts of the historical actors are to be taken seriously (Kurunmäki 2014).

Moreover, it appears doubtful whether the democratization process ever can be finished since the very idea of democracy seems to be connected to a continuous strive for something that cannot be finalized. Even when trying to pin down democracy as a type of regime, this does not give democracy finality. As Pierre Rosanvallon $(2006,68)$ puts it, 'In fact, democracy is always at one and the same time the clear solution to the modern problem of the institution of society as well as a question forever left unanswered, in the sense that no conclusive and perfectly adequate response can ever be provided to it.' Thus, every democratization process is a forever continuous process. Instead, Rosanvallon (ibid., 38) suggests, 'one must see that democracy is a history. It has been a work irreducibly involving exploration and experimentation, in its attempts to understand and elaborate itself.' However, conceptual history has shown how political concepts are always spatially and temporally situated. Hence, as the meanings of political concepts change over time, it becomes problematic to make long-term claims for the future, which is why the legitimatization of a long-term democratic project must continuously be carried out in the short term.

\footnotetext{
${ }^{1}$ This means that debates on industrial and economic democracy are intentionally left out (for debates on these issues, see e.g. Friberg 2013; Kärrylä 2019).

2 This was, however, not without limitations. There were still several limitations against those who were dependent on poor relief, had not fulfilled their military service, had a criminal record, were bankrupt, were deemed minors because of mental incapacities, or were part of nomadic groups (Berg et al. 2018).
} 


\section{Debating Democracy after the First World War}

The experiences of the First World War provided impetus for political reforms all across Europe. The war, together with the revolutions in Russia and Germany, has been characterized as a test of the credibility and legitimacy of the power of states, which resulted in changing understandings of concepts such as democracy, parliamentarism, and state. The war experiences became a force that mobilized and politicized the public, a politicization that turned into calls for extended political participation. In the aftermath of the Russian February Revolution, both the great powers engaged in the war and smaller nations that were not directly involved experienced a resurgence of constitutional disputes that had been postponed in 1914. The disputes that followed concerned both the appropriate solutions to the crises that were arising from the wartime conditions and the implications of the international developments for the national constitutions (Ihalainen 2017; Ihalainen 2019; Jakobsen \& Kurunmäki 2016). This was also the case in Sweden, where a reconstruction of polity - by trying to reconcile national traditions with foreign models - took place alongside ideologically motivated interpretations of time, e.g. the history of the constitution and its future development.

During the end of the Great War, there was an ideological struggle over how the history of the Swedish constitution should be interpreted. The conservative Professor Pontus Fahlbeck - who opposed universal suffrage - supported the constitution of 1809, in which the monarchy and the First Chamber balanced a potentially radical Second Chamber. According to Fahlbeck, this was a Swedish version of limited democracy and dualistic parliamentarism. A contrasting perspective was advocated by the leftist Dr. Fredrik Lagerroth, who described the history of the Swedish constitution as a long-term struggle between autocracy and constitutionalism. From Lagerroth's perspective, Sweden was a democracy of ancient origin in which the Gustavian Age had merely been a short pause (Ihalainen 2015). In particular, the Lagerrothian perspective would influence arguments on the further democratization of the Swedish constitution.

Politically, the 1920s in Sweden were characterized by weak governments without parliamentary majorities. The Social Democratic Party had experienced an internal ideological struggle which reached its climax in 1917, when the Left wing of the party broke off and formed the Social Democratic Left Party (hereafter, the Left Party). The Left Party would later, in 1921, turn bolshevist after accepting the 21 conditions of the Comintern and change its name to the Swedish Communist Party. However, throughout the Interwar Years, the radical Left would be politically marginalized in the Riksdag. In the spring of 1917, there were Leftist threats of a revolution in Sweden, and in 1918 the nation feared developments similar to those that had taken place in Finland and Germany. The international development and a fear of national confrontations led to intensified debates, after which the Right gave in and the Riksdag was able to pass the bill on universal suffrage for both men and women. This replaced the earlier unequal suffrage - based on 40 classes of voters - in municipal elections (Ihalainen 2019; Torstendahl 1969). During the spring of 1919, women's voting rights were extended to include national elections. To the Social Democrats and the Liberals, the suffrage reforms were important victories, which were interpreted to mark the start of a new democratic era.

\section{The Present, a Momentary Time of Transition or a Time of Contemplation? The Issue of a Unicameral Parliamentary System}

The Swedish two-chamber parliamentary system, which dated back to the Riksdag Act of 1866, was based on the idea that the Second Chamber would represent short-term political opinions whereas the First would have a more conservative character in order to eliminate 
the risk of haphazard decisions. The seats in the Second Chamber were distributed directly in relation to elections by the entitled voters whilst the First was elected indirectly by municipal councils. This system benefited the wealthier classes due to high tax and property qualifications. Political actors who advocated a unicameral parliamentary system saw themselves as being on the high road to success because a unicameral reform was thought of as a democratic reform, being a natural development after the newly reformed franchise. In other words, the experiences of the franchise reform opened the horizon and created expectations of more reforms in the name of democracy.

The remaking of the Riksdag into a unicameral parliament was primarily advocated by representatives of the radical Left. Carl Lindhagen (1919a), who represented the Left Party but never turned bolshevist, argued that because both chambers were elected from the same voters, this would result in two chambers without any special characteristics. This argument had previously been used by Ernst Trygger, leader of the Right in the First Chamber, as a reason to dismiss universal suffrage in municipal elections (Jakobsen \& Kurunmäki 2016). In 1919, the Left Party described the constitutional past as a political system that was oppressing the people through plutocratic privileges and restraints on social development. Democracy was presented as the principle that would lead the people forward and free them from oppression. According to the Left Party, a unicameral system was an inevitable step to take after the franchise reforms; it was 'a progressive element of society' (Vennerström et al. 1919a, 10). ${ }^{3}$ The Leftists were thus using a Marxist understanding of history and a deterministic narrative of the Swedish democratization process by emphasizing how earlier democratic reforms had immediate relevance in the present. ${ }^{4}$ In other words, the past reached into the present and constituted a basis for further democratic changes. The Social Democrats, on the other hand, had a different interpretation of the past when they argued that it was too soon after the franchise reforms to decide on the parliamentary organization. Arthur Engberg (1919, 6), a member of the party executive, stated that the 'new democracy' needed time to evaluate which parliamentary system best suited its purposes. No lessons could be immediately drawn from the past; instead there was a need to contemplate on the experiences of the franchise reforms. At the time, Engberg declared, 'democracy is in need of a certain degree of self-control', thus referencing the moderating character of the First Chamber. By arguing that past reforms had to be evaluated before deciding on any future ones, the temporality of democracy was - in Engberg's rhetoric - primarily present-oriented, i.e. it was now time to stop and think before possibly acting again. Hence, the Left Party had an interpretation of the past that clashed against the Social Democratic understanding of previous reforms. The different interpretations of the past led to differing ideas on how the future should be shaped. At this point, however, it is worth noting that the Social Democrats expected electoral growth in the upcoming First Chamber election, and in 1921 they became the largest party in both chambers.

The debate followed similar lines in 1920, when the Left Party argued that the removal of the First Chamber would be 'a further democratization of the constitution' (Hage et al. $1920,1)$. A reform of this kind would thus connect the past to the present. Referencing the reform of 1919, Carl Winberg (1920) pointed to how the First Chamber had lost its earlier function and consequently should be removed. To the Left Party, the future-oriented temporality of democracy made many traditional features seem obsolete. The Social Democratic

\footnotetext{
${ }^{3}$ Unless otherwise indicated, all translations are the author's own.

4 The question of determinism in Marxism is a highly debated field. However, this is a theoretical discussion that is outside of the focus of this article.
} 
manifesto of 1920 called for 'a democratic system of representation'. ${ }^{5}$ In the Riksdag, the Social Democrats were attacked by the Left Party for not supporting the bill, in the light of the fact that the Danish Social Democrats advocated the very same institutional reform. Once again, however, the Social Democrats claimed that it was too soon to decide which system best favored democracy (e.g. Hage 1920a; Larsson 1920a). The argument was also shared by the conservative National Party's Knut von Geijer (1920), who stated that the issue could not be resolved until the consequences of the franchise reforms were fully visible, i.e. after elections to both chambers were fulfilled.

In 1922, Carl Lindhagen $(1922,1)$, by this time a party independent, argued that 'history has finished a chapter' and that 'a new era' was approaching. The present was consequently classified as a 'stage of transition'. The experiences created explicit expectations for a continuous development, and democracy was understood by the radical Leftists as process that reached into the future, albeit with immediate demands. Referencing earlier counterarguments, the Left Party's Ivar Vennerström (1922) pointed to the fact that elections to both chambers had been completed. The radical Leftists understood the present as a transition period in a progressive development, moving from an old polity to a new and better one. Once again, the Marxist determinist perspective on history became visible as the past was portrayed as old and obsolete while the future was understood as something positive gazing at the horizon. To the radical Leftists, expectations for the future were more important than any experiences from the past. Arthur Engberg (1922) stated that while the Social Democratic manifesto did include 'a democratic system of representation', democracy was emphasized over any particular parliamentary system. Given the unstable parliamentary situation, the Social Democrats were careful not to provoke the Right or to give in to the demands of the Left Party.

In 1924, the Communist Party petitioned a bill on a unicameral system by removing the First Chamber (Molander et al. 1924). Carl Winberg (1924a) argued that it was of utter importance to reform the Riksdag if it was to survive in a time when parliamentarism and democracy were heavily criticized. History was marching forward, and it was a matter of trying to keep up. Mauritz Hellberg (1924), a leading Liberal, advocated in favor of keeping the two-chamber system with reference to the moderating character of the First Chamber. However, the Social Democrat Erik Fast $(1924,74)$ claimed that this kind of 'precaution for democracy' was superfluous due to the 'calm and levelheaded nature' of the Swedish people. By the mid-1920s, this issue divided the Social Democrats. Arthur Engberg continuously argued that it was too soon to decide. Referencing the constitutional crisis of 1914 - when the king openly took a stand against the anti-militaristic policy of the government - Engberg (1924a, 82) claimed that there might be a need for a 'democratic Upper House' rather than a 'miscellaneous colored majority with reactionary features'. Engberg was thus, this time alongside Hellberg, emphasizing a present-oriented temporality of democracy. Democracy was something that existed in the present through previous reforms; the past did not need to be supplemented. However, other Social Democrats advocated a reform, such as Mauritz Västberg $(1924,77)$, who stated that the First Chamber was a hindrance to 'the full realization of universal suffrage', and Ernst Hage $(1924,80)$, who argued that 'a democratic structure' was based on a number of pillars, amongst which were a unicameral parliamentary system. The statements from Västberg and Hage emphasized a future-oriented temporality of democracy and were indicative of the way many Social Democrats understood a unicameral system, as a consequence of the franchise reform, and as a step toward a fuller and more complete democracy.

\footnotetext{
${ }^{5}$ This formulation had been heavily discussed during the party congress, as the committee drafting the new manifesto had suggested an explicit reference to the unicameral system (Friberg 2013, 98-99).
} 
The debates on the parliamentary system show how the radical Left continuously emphasized a future-laden temporality of democracy; democracy was understood as something that would be fully realized in a distant future. However, the process toward this fully democratic society had already begun - by past reforms - and it was important to continue in the same direction. The present was consequently seen as a transitional period in this teleological narrative between the past and the future. The arguments in favor of a parliamentary reform clearly emphasized hopes and dreams for the future, alongside the desire to break free from the restraints of the past. Going back to the earlier discussion on the relationship between perceptions of time and linguistic expressions, in Koselleckian terms, the horizon of expectation was more important than the space of experience. Thus, in the rhetoric of the Left Party, the Marxist determinist perspective on history was evident. The party's representatives understood their own present as a momentaneous now that was situated between a past that had been worse and a future that would inevitably be better. However, in the light of the recent war and earlier national political reforms, the majority in the Riksdag described the present as a time of uncertainty. There was a need for contemplation rather than hasty decisions. The temporality of democracy was, to the majority, present-oriented. Democracy was seen as something won through the reformed franchise. It was thus an element of the present, and the issue of further democratization was a matter that should not be rushed. In other words, the space of experience needed to be larger in order to decide how the future should be shaped. Thus, the above debates show how there was an ideological struggle over the correct interpretation of the past as a way of conquering the future.

\section{A Swedish Democratic Tradition: Debating the Referendum as Continuity or Radical Novelty}

After the suffrage reforms, increasing calls were made to further extend public political participation by introducing the institute of referendum. Internationally, this was a highly debated issue. In particular, the Weimar constitution became an important backdrop against which the Swedish debate took place. However, the arguments in the Riksdag were surprisingly nationally oriented despite the ongoing transnational debate (on the transnational debate, see Ihalainen 2017). Moreover, the need for referenda as a means of implementing political power was reinforced by the long struggle over the prohibition of alcohol, in which the Riksdag seemed to have reached a standstill. The issue of alcohol prohibition had been debated since the turn of the century as the high consumption was linked to numerous social problems and consequently high societal costs. Those advocating a complete ban gained strength during the 1910s - when both Norway and Finland introduced limitations - and in 1917, public access to alcohol was limited through a ration book system. The issue of alcohol prohibition became intertwined with the referendum issue in August 1920, when the committee working on the question of alcohol prohibition issued a report stating that a referendum would be a suitable means to resolve the matter (Johansson 1995). The parliamentary debates of the referenda primarily concerned the consultative referendum, while the possibility of a decisive referendum was merely touched upon. Nonetheless, the two types of referenda were not debated as separate issues but as interconnected ones. The decisive referendum was most often referred to when arguing that even a consultative referendum might in practice be decisive.

In 1919, the introduction of the referendum was advocated by the active Carl Lindhagen (1919b), who argued that the 'old democracy' had ceased to evolve and that universal suffrage in parliamentary elections did not equal democracy. 'True democracy', according to Lindhagen's leftist view, was to be understood as the people's right to be masters in their own houses. In the Riksdag, Lindhagen received support from the conservative Sam Clason 
of the National Party. However, unlike Lindhagen, Clason expected the institute to have a moderating effect on the development of the constitution. As an argument in favor of this claim, Clason (1919) pointed to a number of foreign examples where the institute had been realized. However, Clason's party comrades had a different view on the matter and argued that other nations were irrelevant to the Swedish case (e.g. von Mentzer 1919). References to the past were often used by those opposing the referenda, for example Otto von Zweigbergk $(1919,13)$ of the Liberals, who referred to 'the history of the referendum' and stated that 'there are absolutely no cases where this institute has been tried and found useful.' Following von Zweigbergk's line of thought, the space of experience imposed limitations on the present political possibilities.

One of the main arguments in favor of referenda was that the introduction would constitute a 'democratic reform'. The Social Democrats argued that: 'No one can deny that the demand for the referendum is a democratic demand belonging to a democratic order' (Larsson 1919, 12). In other words, if the present was a democratic time, the absence of referenda was a temporal anomaly, i.e. the institute should already exist in such an order. It was also stated that previous constitutional reforms should be understood as impetuses for further democratization (Engberg 1919). Democratization was hence thought of as a continuous process that had already begun and was marching forward with increasing pace. It was now a matter of keeping up. The necessity of the institute in a democratic society was, however, contested from various points of view. Von Zweigbergk (1919) pointed to the fact that the ideals that the referendum carried were very similar to those that had been put forward during the franchise debates. According to von Zweigbergk, these ideals would never be realized as they were too utopian. The democratic ideals of equality and public participation reached so far into the future that any concrete attempts to realize them would always fall short in the present. There were also arguments stating that referenda would be a return to earlier versions of democracy, referencing the legacy of the Viking-Age style of governance by assembly (ting). For instance, the Liberals' Anders Olsson $(1919,17)$ stated that 'the reform can, from a formal point of view, be called democratic, but I fear that it would be a too primitive democracy.' Olsson can thus be said to have turned the Lagerrothian argument against its proponents, by admitting a past tradition of democracy but simultaneously highlighting its progressive development. In this way, the struggle over the correct interpretation of the past became redundant.

Arguments in favor of the institute continuously involved temporal notions to show how this was a reform that would inevitably be brought about. For instance, the Left Party stated that 'the demand for the referendum is marching forward' (Vennerström et al. 1920, 6), and the Liberals' Fredrik Holmquist $(1920,20)$ claimed that 'it will not be long until we are faced with the necessity of referenda.' These arguments highlighted ideas about a future that called for a mobilization of actions in the present. There were also arguments following Clason's line of thought, i.e. that the referendum would balance universal suffrage. As the Liberals' Ulrik Leander $(1920,6)$ stated, it would be 'a means to the self-control of democracy' due to its potential to hinder any hasty decisions.

Part of the debate concerned whether foreign examples were of relevance to the Swedish case. Those in favor of the institute persistently argued that any survey would show that the institute would be beneficial in Sweden (e.g. Clason 1920; Larsson 1920b). Attempts were thus made to construct a space of experience, both temporally and spatially, by referencing foreign examples. Reformists, such as the Social Democratic leader Hjalmar Branting, referred to an ongoing global revolution, in which Sweden was lagging behind (Ihalainen 2017). Once again, the future was portrayed as more important than the present or the past, and it was a 
matter of keeping up with a perceived rush toward the future. However, this view was contested, for instance by the National Party's Erland von Hofsten (1920, 12), who stated that the referendum would be a 'radical novelty' that was 'completely alien to the spirit of the constitution and its natural development.' According to von Hofsten, the referendum would interfere with a historical continuum and its linear development. Here, the ideological struggle concerned the present; whether it should be guided by the past or by the future.

References to the constitution were used to underline historical legacy and legitimacy. Nils Alexanderson $(1920,29)$ of the Liberals argued that the constitutional phrase the Riksdag represents the Swedish people' was 'a historically funded phrase', directed at the idea that the people could be represented by any other body. The idea of introducing a new element of public representation was thus rejected with reference to the constitutional legacy. Carl Reuterskiöld, an independent conservative, stated that the balance between the two powers of the king and the Riksdag had been disturbed. However, Reuterskiöld (1920, 15-16) continued, 'it is too soon to determine whether the attacks on the constitution carried out in 1918 and 1919 will have the consequences that some people imagine.' Reuterskiöld's argument was thus closely linked to von Hofsten's, as they both emphasized how the present should be understood as a linear continuum reaching from the past into the future; any breaks in this development were consequently seen as abnormalities.

The debate was intensified after February 8, 1921, when the Referendum Committee presented a report suggesting an introduction of the consultative referendum (Folkomröstningskommittén 1921). According to the Social Democrat August Sävström (1921), the development of the state had brought about such a change that the referendum was a necessary step. To the Liberals, the World War had resulted in a state that needed an institution for the acquisition of the public opinion, and the referendum was said to be such a feature of 'modern democracy' (Edén et al. 1921). In other words, the present democracy was unfulfilled without the institute of referendum. As in the previous debates, the Right opposed the relevance of foreign experiences (e.g. Pehrsson 1921; von Geijer 1921). References to the past were repeatedly used by the Conservatives, especially when arguing that the institute did not fit with Swedish traditions. The Peasant Party's Karl Starbäck (1921, 44) stated that the referendum 'is not in agreement with the traditional Swedish conception of justice', and the Liberal August Ljunggren $(1921,52)$ argued that the Riksdag should keep 'the ancient tradition and deeply rooted regulation' that it alone constituted the representation of the Swedish people. According to Starbäck and Ljunggren, the referendum would be an interference with the traditions of an ancient Swedish democracy.

Moreover, the opponents of the referendum argued that the democratization seemed like a never-ending process. As the institute was put forward as a 'democratic demand', its opponents asked the question 'When will democracy be fulfilled?' (Johansson 1921, 58). The temporality of democracy was thus portrayed as reaching too far into the future. It was something without finality which led to a plethora of democratic demands that never ceased. Ernst Trygger $(1921,48)$ posed the idea that 'democracy seems to feel regret over its large victory [universal suffrage]' and asked whether the referenda were a way for the Riksdag to distance itself from the responsibility it had gained through the recent reforms. On the other hand, the proponents of the referendum emphasized a future-oriented temporality of democracy when arguing that the present institutions were antiquated (e.g. Nilsson 1921). According to these proponents, society 'had entered a new stage' (Edén 1921, 36). Hjalmar Branting (1921, 63) stated that 'the referendum is a step in the development of the democratization that the world is striving towards.' Thus, according to Branting, the present had to adapt to the future. Here, the focus of attention was on how close or far the present and the future were from 
each other. To the joint Left - the Left Party, the Social Democrats, and the Liberals - the present was understood as approaching a fully democratic future through political reforms, while the Conservatives argued that such a future was merely an imagined utopia that could never be reached.

The referendum debate reached its end in 1922, when the institute was introduced. The debates of 1922 were, in many ways, a summary of earlier arguments, especially the counterarguments; namely, that the introduction of referenda would be 'a retrogression to a primitive form of democracy' (Geijer 1922, 10-11); that the timing of the reform was poorly chosen, either because of the uncertainty of the long-term effects of the franchise reforms or due to the unstable economic and political situation in Southern Europe (Trygger 1922); that there was no clear international tendency toward referenda (Lindman 1922); or that the institute had nothing to do with democracy (von Geijer 1922). In view of the above arguments, the most debated issue was whether or not the institute was of relevance to democracy. The existing system was legitimized through the use of historical references. It was, for example, stated that 'the representative system is, since ancient times, ours' (ibid., 12). The Right was thus reproducing the Fahlbeckian interpretation of the Swedish constitution as a limited democracy. Despite the conservative counterarguments, the Riksdag passed the Referendum Bill, and later that year, on August 27, a referendum was held on the prohibition question.

The above examples show how actors both for and against the referendum used notions of temporality to strengthen their arguments. During the immediate post-First World War period, both the Left and the Right could argue in favor of the institute; to the Left, it was a tool to expedite a democratic progress, while the Right understood it as a means to impede the very same development. It is worth noting that both sides understood democracy as a concept with a future-oriented temporality. The Right would, however, increasingly oppose the referendum. A number of historical references were used to emphasize the importance of continuity in the constitutional development by arguing that the institute would clash with Swedish traditions. To the Right, a continuity of the past was more important than any new expectations for the future. At the same time, the joint Left also used continuity as a legitimizing argument when stating that referenda were a consequence of the introduction of universal suffrage, thereby stressing the Lagerrothian argument of a Swedish democratic tradition. Thus, like the debates on a unicameral parliament, these discussions about interpretations of the past should be understood as a means of getting an interpretative prerogative of the future. During the early debates, the Right refuted any attempts to create a space of experience by using foreign examples, but in 1922, they repeatedly referred to other nations when arguing that the international development did not move towards the introduction of the referendum.

\section{A Relic from the Past or a Modern Democratic Form of State? The Question of Monarchy or Republic}

The joint Left had long advocated a republican form of state, although with varying degrees of intensity. When the German monarchy, which had been important for debates on the Swedish constitution, had fallen, and a number of republican states were formed after the war, the debate gained new impetus even in a traditional monarchy like Sweden.

In 1919, the Left Party petitioned a bill to investigate whether the Swedish people preferred a republican form of state. The Left Party argued that 'There is no longer anything challenging about being a republican. Rather, it is the other way around; the monarchy is starting to look challenging and odd' (Vennerström et al. 1919b, 3-4). References to the new states of the war were made in stating that 'quite thoroughly, the republican form of state seems to be a given.' The present was thus understood as a new time where old traditions had become 
anachronistic. As Mauritz Hellberg (1919, 33-34) argued, 'A new time has begun. This is not a hollow phrase but a reality with the deepest and most important meaning.' Hellberg emphasized the fact that the republic was 'the only form of state which is in full agreement with democracy.' The present was in this way seen as a transitional period, hence there was a need to re-evaluate and reform society. In line with Hellberg, the Social Democrat Oscar Olsson $(1919,39)$ stated that the demand for a republic was not only inspired by revolutions in Europe but also derived from national experiences. More specifically, Olsson pointed to 'the large democratic breakthrough [universal suffrage]', and the idea that 'in a democratic society, institutions must be manifestations of the people's will.' He then concluded, 'No one would claim that the hereditary monarchy is a manifestation of the will of the people.' Furthermore, the fact of appointing someone king on the principle of hereditary right came to be referred to as a 'decapitation of democracy' (Hellberg 1919, 32). The consequences of past reforms were thus seen as demanding reforms in the present. However, the Conservatives argued that 'democracy is not an end in itself' (Trygger 1919, 36). According to the Right, it was the benefit of the nation that was most important. Even if a republican form of state was more in harmony with democratic ideals, such as equality and participation, this did not necessarily mean that Sweden should introduce a republican form of state.

In the rather brief debate on the matter in 1920, references to foreign countries were continuously heard, e.g. that a number of European monarchies had been overthrown and replaced by republican forms of state (e.g. Hellberg 1920; Werner 1920). Arthur Engberg $(1920,33)$ argued that 'the hereditary monarchy has been shown to be a relic from past times which one as a democrat has no reason to protect.' The monarchy was thus understood as belonging to a past time while democracy was something for the future. The monarchical institution was also presented as degrading to the people. According to Ernst Hage (1920b, 28), 'It is humiliating to a people to be inherited within a particular family just like the farmer's cows are inherited within the family of the farmer.' It should be noted that this was an issue that divided the joint Left. While the Social Democratic manifesto included a demand for a republican form of state, party members increasingly refuted the idea of replacing the monarchy with a republican form of state. For instance, Harald Hallén (1920) stated that the hereditary monarchy was neither undemocratic nor had it hindered the democratic development of Sweden. The increasing Social Democratic reluctance toward the reform should be understood against the backdrop of international revolutions and civil wars, as well as a general fear of confrontation in the wake of the Great War. In addition, despite their overall positive perspective on a republican form of state, the Social Democrats did not want to be associated with the Left Party, which, at this time, was becoming increasingly bolshevist.

In 1924, the Communists argued that the monarchy was nothing but 'a relic from the past'; it was hence incompatible with the present order of society. The time had come to 'consequently apply democracy', which required the removal of the monarchy (Spångberg et al. $1924,7)$. To the Communists, the present was understood as the beginning of a new time, one that would be completely democratic. The Communist understanding of democracy was closely tied to the idea of the classless society. All instances of what the Communists perceived as unjust or unfair were consequently deemed 'undemocratic' and refuted. In the Riksdag, Carl Winberg (1924b, 17) stated that it was 'impossible to have a rational, modern, and truly democratic society ... whilst keeping the hereditary monarchy.' The monarchy was in this way understood as an obsolete element of the past (e.g. Spångberg 1924, 4). At the same time, the Conservatives used historical references to highlight the historical importance of the tradition of the Swedish monarchy; something that should not be broken easily. Once again, traditions were used to highlight a continuity that was more important than any novel expectations. The Peasant Party's Claes Lindskog $(1924,8)$ offered an international vista when 
arguing that the reason the United Kingdom had not transitioned from a monarchy to a republic was because 'they have an understanding of what centuries of inherited tradition mean.' Furthermore, the Right argued that the idea of a king was so deeply rooted within the minds of the Swedish people that its removal would be against the will of the people and hence undemocratic (Björkman 1924). In this case, the battle over temporalities primarily concerned the present as a means of claiming the future; whether it should be understood as a momentary phase of transition in an inevitably continuous process or as a continuation of the past.

The Social Democrats were rather passive in these debates, and leading party members avoided choosing sides, arguing that the form of polity should not be the focus of attention but rather that 'democracy with universal suffrage' would constitute its foundation (Engberg $1924 b, 19)$. Whether a republican form of state was more democratic than a monarchical one was seen as an open question. This was stated with special reference to the Soviet Republic, which was argued by Arthur Engberg to be 'the least democratic [republic] in the world.' However, Engberg also stated that, in principle, 'a logic conclusion of universal suffrage' would be that 'the Head of State should be given his position based not on breeding but on merits', drawing on an expression from Lloyd George. To the Social Democrats, the temporality of democracy was present-oriented. As in the case of the parliamentary system, the present was a time for contemplation rather than radical changes; the past did not require anything from the present.

The debates on a republican form of state in Sweden were inspired by European revolutionary movements that had overthrown monarchs and replaced them with presidents. The radical Left understood the present as the beginning of a new time. The experiences of other European nations inspired a positive outlook on the future, as the radical Left envisaged that Sweden would follow their examples. The monarchy was put forward as an anachronistic element in a future-oriented present. However, the Conservatives argued that the monarchy was fully democratic, i.e. in accordance with the will of the people due to its long tradition.

\section{Concluding Remarks: Visions of Democracy and the Category of the Utopian}

This study has shown how the historical actors continuously used features of temporality to strengthen their arguments for further democratization or to argue against the very same development. More precisely, the political argumentation was based on different interpretations of the historical development, resulting in varying understandings of the present as well as differing visions of how the future should be shaped. As the study has shown, fragments from the past called for attention in the present and demanded responses, the present interacted with the future by setting the scene, and the future mobilized expectations (and actions) in the present. There has thus been a continuous interplay between the contingency of the different temporalities.

To the joint Left, and to the radical socialists/communists in particular, the present was in many ways understood as a period of transition that would inevitably lead to a democratic future. Thus, not surprisingly, these parties used a Marxist sense of history in their argumentation of an optimistic and deterministic development of society. In the radical Left rhetoric, past reforms were put forward as having far-reaching temporal consequences, i.e. the reforms reached into the present and demanded further reforms. Above all, it was the future that was the guiding temporality; the present should consequently adapt according to the expectations of a future that was often presented as a fait accompli. The reforms were thus legitimized by this deterministic understanding of history. Hence, a teleological narrative about Swedish democratization was emphasized by means of the Lagerrothian argument as a 
source of inspiration, and the temporality of democracy was clearly future-oriented. However, the radical Leftists' expectations should not be interpreted as a fully linear understanding of history. The argumentation of an inevitable future, which sometimes took on almost messianic dimensions, could also be seen as containing cyclical understandings of time, i.e. the cyclical and linear did not exclude each other but rather the former enhanced the latter. By introducing a cyclical time, the past was connected to the future, and history was portrayed as determined (Jonsson 2017; Nygaard 2012).

While the radical Left advocated that the present should change according to an envisaged future, the Social Democrats were more hesitant, emphasizing the present as a time for contemplation and reflection in order to fully learn the lessons of the past. Any future democratic reforms had to wait until the experiences of universal suffrage could be evaluated. Thus, the Social Democratic focus was on the present rather than the future. On an ideological level, the Social Democrats were in favor of the democratic reforms but given the unstable political situation - both nationally and internationally - the party avoided making statements that could be accused of leading to a socialist future. In addition, this was also a time for the Social Democrats to consolidate their gains after the suffrage struggle and to mark their distance from the radical Left, which was becoming increasingly communist/bolshevist. Any radical demands were thus downplayed in favor of opposing bolshevism. The Liberals took a rather conservative stand in many of these debates, often referring to Swedish traditions and the need for precaution in regard to democracy. In other words, the past and the present were seen as more important than any ideas about how the future could or should be shaped. It is, of course, also worth mentioning that, like the Social Democrats, the Liberals had been active in the franchise struggle and now wished for consolidation.

To the Conservatives, continuity was, of course, central, and universal suffrage was in many ways understood as a break in a linear development. This led the Conservatives to fight off so-called democratic reforms by using references to Swedish traditions or historical legacy. Democracy was understood and legitimized in relation to its Swedish history. Thus, the Fahlbeckian interpretation of the Swedish constitution as a limited democracy was, albeit implicitly, present in many of the conservative statements about democracy. The Rightist understanding of history highlighted a linear development where the past was its guiding temporality. This led the Right to criticize Leftist understandings of democracy as too futureoriented, i.e. it was something that could never be finalized. Any hopes the Right had about future democracy contained nostalgic elements.

The temporalities of democracy that were put forward can be understood as reflecting the ideological habitats of the political actors; e.g. the Conservatives emphasized national traditions and tried to fight off anything that was understood as interfering with a linear history-driven development, while the radical Left, on the other hand, emphasized a futuredriven history. Besides the obvious ideological heritage of a Marxist theory of history, the Leftist understanding of democracy can also be understood through Rosanvallon's claim of democracy as a continuous long-term project that can never be finalized. Any finality can only be realized in the momentum, i.e. through reforms set in a short-term perspective. However, ideological projects of this kind always reach into the future and require further changes. This long-term perspective seems to derive from an understanding of the concept of solidarity as a principle of equality. The consequence of this interpretation is that it is always possible to place further demands on a democratic society as it is always possible to strive for more equality. Hence, political projects that are grounded in concepts such as justice or equality become continuous and to some degree undefined. 


\section{The Category of the Utopian}

On a more theoretical level, the study has shown how the Koselleckian categories of space of experience and horizon of expectation have been constructed through rhetorical redescriptions in order to function as political arguments. Hence, there has always been an ideological struggle over temporalities, i.e. how the past should be understood, how the future should be shaped, and consequently what is required from the present in relation to these temporal interpretations. For example, the past was used and politicized in a number of ways; from being described as something to break free from, e.g. plutocratic privileges, to being put forward as something to preserve, e.g. deeply rooted traditions.

While the argumentation for the concrete democratic reforms included elements of experience and expectation, the idea of a complete (political) democracy should be understood as having transcended the category of expectation. As the study has shown, the political actors motivated their arguments concerning the reforms by horizons of expectation, i.e. what they thought would lead to a more democratic society. However, the very idea of a more democratic society implies that there is yet another dimension beyond the society shaped by the reforms addressed in this study, which would therefore not make it a complete democracy. The vision of a complete democracy was given such a future-oriented temporality that it cannot be understood as something that the actors expected but rather as something that they hoped for, dreamed of, or sometimes feared. Thus, the vision of a complete democracy was not clear on a horizon of expectation available to the historical actors of this time, i.e. it was something normative rather than empirically possible. To make this kind of thinking fully transparent, there is a need for an analytical division of future perspectives. Rather that discussing visions of the future as one coherent category, we should make a distinction between one category of horizon of expectations that relates to prognoses, predictions, and anticipations, and one category of the utopian that involves long-term possibilities and opportunities that lie beyond any empirically expectational horizons (see also Escudier 2011). The introduction of the category of the utopian has the advantage of keeping the categories of experience and expectation interconnected while it also can help us understand the long-termness of politics.

By introducing the category of the utopian, the long-termness of politics is highlighted. Political actors are motivated not only by what they expect, i.e. by calculable prognoses, but also by hopes, dreams, and wishes, even if these cannot be fully defined in terms of finality. Utopian visions may be illusions, but they derive from actual dreams and hopes. Furthermore, they reflect the historical tension between factual states and distant goals, and as such they can be expressed politically in the short term. The proposed reforms that have been analyzed in this article did not derive from dreams of a state in which these reforms had been introduced. Put differently, the future-oriented goal was, for instance, not so much a state in which the referenda existed but rather a state in which the referenda were a sign of something more; a complete democracy. The utopian should thus be understood as a historically grounded analytical category aiming to understand how humans have interpreted their present and acted in relation to long-term motives.

\section{Acknowledgements}

This work was supported by Stiftelsen Riksbankens Jubileumsfond.

\section{Competing Interests}

The author has no competing interests to declare. 


\section{References}

Alexius, Katarina. 1997. "Politisk yttrandefrihet: En studie i lagstiftning och praxis under demokratins genombrottstid." PhD diss., Uppsala University.

Ankersmit, Frank. 2002. Political Representation. Stanford, California: Stanford University Press.

Berg, Annika, Martin Ericsson, and Fia Sundevall. 2018. "Rösträtt för alla? Begränsningar i rösträtten efter 1921." In Rösträttens århundrade: Kampen, utvecklingen och framtiden för demokratin i Sverige, edited by Ulrika Holgersson and Lena Wängerud, 219-239, Gothenburg: Makadam förlag i samarbete med Riksbankens jubileumsfond.

Eley, Geoff. 2002. Forging Democracy: The History of the Left in Europe, 1850-2000. Oxford: Oxford University Press.

Escudier, Alexandre. 2011. “Temporalization' and Political Modernity: A Tentative Systematization of the Work of Reinhart Koselleck." In Political Concepts and Time: New Approaches to Conceptual History, edited by Javier Fernández Sebastián, 131-177, Santander: Cantabria University Press.

Folkomröstningskommittén. 1921. Betänkande och förslag angående konsultativ folkomröstning. Stockholm: Nordh. bokh.

Friberg, Anna. 2013. Demokrati bortom politiken: En begreppshistorisk analys av demokratibegreppet inom Sveriges socialdemokratiska arbetareparti 1919-1939. Stockholm: Atlas.

Hadenius, Stig. 1966. Kring demokratins genombrott i Sverige. Stockholm: Wahlström \& Wigstrand.

Ihalainen, Pasi. 2015. "The 18th-Century Traditions of Representation in a New Age of Revolution: History Politics in the Swedish and Finnish Parliaments, 1917-1919." Scandinavian Journal of History 40(1): 70-96. DOI: https://doi.org/10.1080/03468755.2014.987161

Ihalainen, Pasi. 2017. The Springs of Democracy: National and Transnational Debates on Constitutional Reform in the British, German, Swedish and Finnish Parliaments, 1917-1919. Helsinki: Finnish Literature Society. DOI: https://doi.org/10.21435/sfh.24

Ihalainen, Pasi. 2019. "Transnational Constructors of Parliamentary Democracy in Swedish and Finnish Constitutional Controversies, 1917-1919." Scandinavian Journal of History 44(2): 213-235. DOI: https://doi.org/10.1080/03468755.2018.1500943

Ihalainen, Pasi and Tiina Kinnunen. 2019. "Reform and Revolution in Scandinavia, 1917-1919: Entagled Histories and Visions of the Future." Scandinavian Journal of History 44(2): 143-149. DOI: https://doi.org/10.1080/03468755.2018.1511469

Jakobsen, Uffe, and Jussi Kurunmäki. 2016. "The Formation of Parliamentarism in the Nordic Countries from the Napoleonic Wars to the First World War." In Parliament and Parliamentarism: A Comparative History of a European Concept, edited by Pasi Ihalianen, Cornelia Ilie and Kari Palonen, 97-114, New York: Berghahn Books. DOI: https://doi.org/10.2307/j. ctvgs0b7n.11

Johansson, Lennart. 1995. "Systemet lagom: Rusdrycker och politisk kultur under förbudsdebattens tidevarv 1920-1922." PhD diss., Lund University Press.

Jonsson, Karin. 2017. "Fångna i begreppen? Revolution, tid och politik i svensk socialistisk press, 1917-1924." PhD diss., Södertörn University.

Kärrylä, Ilkka. 2019. "The Contested Relationship of Democracy and the Economy: Debates on Economic and Industrial Democracy in Finland and Sweden, 1960s-1990s." PhD diss., University of Helsinki.

Koselleck, Reinhart. 2004. Futures Past: On the Semantics of Historical Times. New York: Columbia University Press. 
Kurunmäki, Jussi. 2014. "Rhetoric against Rhetoric: Swedish Parliamentarism and the Interwar Period." In The Politics of Dissensus: Parliament in Debate, edited by Kari Palonen, José Maria Rosales, and Tapani Turkka, 171-199. Santander: Cantabria University Press.

Nygaard, Bertel. 2012. Revolution: Masser af modstand. Aarhus: Aarhus universitetsforlag.

Olsen, Niklas. 2012. History in the Plural: An Introduction to the Work of Reinhart Koselleck. Oxford: Berghahn Books.

Olsson, Stefan. 2000. "Den svenska högerns anpassning till demokratin." PhD diss., Uppsala University.

Rosanvallon, Pierre. 2006. Democracy Past and Future. New York: Columbia University Press.

Torstendahl, Rolf. 1969. Mellan nykonservatism och liberalism: Idébrytningar inom högern och bondepartierna 1918-1934. Stockholm: Svenska bokförlaget.

\section{Primary sources}

Alexanderson, Nils. 1920. Första kammarens protokoll, May 12, 1920, no. 46.

Björkman, Gustaf Adolf. 1924. Andra kammarens protokoll, April 10, 1924, no. 28.

Branting, Hjalmar. 1921. Andra kammarens protokoll, May 4, 1921, no. 38.

Clason, Sam. 1919. Första kammarens protokoll, June 5, 1919, no. 53.

Clason, Sam. 1920. Första kammarens protokoll, May 12, 1920, no. 46.

Edén, Nils. 1921. Andra kammarens protokoll, May 4, 1921, no. 38.

Edén, Nils et al. 1921. Riksdag bill no. 266, "Om införande av konsultativ folkomröstning." Andra kammarens protokoll, February 20, 1921.

Engberg, Arthur. 1919. Andra kammarens protokoll, June 5, 1919, no. 66.

Engberg, Arthur. 1920. Andra kammarens protokoll, May 12, 1920, no. 56.

Engberg, Arthur. 1922. Andra kammarens protokoll, March 22, 1922, no. 21.

Engberg, Arthur. 1924a. Andra kammarens protokoll, March 12, 1924, no. 18.

Engberg, Arthur. 1924b. Andra kammarens protokoll, April 10, 1924, no. 28.

Fast, Erik. 1924. Andra kammarens protokoll, March 12, 1924, no. 18.

Hage, Ernst. 1920a. Andra kammarens protokoll, April 10, 1920, no. 38.

Hage, Ernst. 1920b. Andra kammarens protokoll, May 12, 1920, no. 56.

Hage, Ernst. 1924. Andra kammarens protokoll, March 12, 1924, no. 18.

Hage, Ernst et al. 1920. Riksdag bill no. 148, "Om avskaffande av första kammaren och införande av enkammarsystem." Andra kammarens protokoll, January 22, 1920.

Hallén, Harald. 1920. Andra kammarens protokoll, May 12, 1920, no. 31.

Hellberg, Mauritz. 1919. Första kammarens protokoll, June 5, 1919, no. 53.

Hellberg, Mauritz. 1920. Första kammarens protokoll, May 12, 1920, no. 46.

Hellberg, Mauritz. 1924. Första kammarens protokoll, March 12, 1924, no. 19.

Holmquist, Fredrik. 1920. Första kammarens protokoll, May 12, 1920, no. 46.

Johansson, Johan Bernard. 1921. Första kammarens protokoll, May 4, 1921, no. 31.

Larsson, Viktor. 1919. Andra kammarens protokoll, June 5, 1919, no. 66.

Larsson, Viktor. 1920a. Andra kammarens protokoll, April 10, 1920, no. 38.

Larsson, Viktor. 1920b. Andra kammarens protokoll, May 12, 1920, no. 56.

Leander, Ulrik. 1920. Första kammarens protokoll, May 12, 1920, no. 46.

Lindhagen, Carl. 1919a. Första kammarens protokoll, June 5, 1919, no. 53.

Lindhagen, Carl. 1919b. Riksdag bill no. 142, "Angående förslag om tillägg till grundlagarne i syfte att åstadkomma verklig folkstyerelse." Första kammarens protokoll, February 20, 1919.

Lindhagen, Carl. 1922. Riksdag bill no. 106, "Angående det nuvarande tvåkammarsystemets avlösning av en mera ändamålsenlig folkrepresentation." Första kammarens protokoll, February 20, 1922. 
Lindman, Arvid. 1922. Andra kammarens protokoll, January 25, 1922, no. 4. Lindskog, Claes. 1924. Andra kammarens protokoll, April 10, 1924, no. 28. Ljunggren, August. 1921. Första kammarens protokoll, May 4, 1921, no. 31.

Molander, Helmer et al. 1924. Riksdag bill no. 258, "Om avskaffande av riksdagens första kammare och införande av ett enkammarsystem." Andra kammarens protokoll, February 20, 1924.

Nilsson, Nils Erik. 1921. Andra kammarens protokoll, May 4, 1921, no. 38.

Olsson, Anders. 1919. Andra kammarens protokoll, June 5, 1919, no. 66.

Olsson, Oscar. 1919. Första kammarens protokoll, June 5, 1919, no. 53.

Pehrson, Per. 1921. Andra kammarens protokoll, May 4, 1921, no. 38.

Reuterskiöld, Carl. 1920. Första kammarens protokoll, May 12, 1920, no. 46.

Sävström, August. 1921. Riksdag bill no. 261, "Om införande av konsultativ folkomröstning." Andra kammarens protokoll, February 19, 1921.

Spångberg, August. 1924. Andra kammarens protokoll, April 10, 1924, no. 28.

Spångberg, August et al. 1924. Riksdag bill no. 359, "Om avskaffande av den ärftliga konungamakten och införande av republik." Andra kammarens protokoll, February 20, 1920.

Starbäck, Karl. 1921. Andra kammarens protokoll, May 4, 1921, no. 38.

Trygger, Ernst. 1919. Första kammarens protokoll, June 5, 1919, no. 53.

Trygger, Ernst. 1921. Första kammarens protokoll, May 4, 1921, no. 31.

Trygger, Ernst. 1922. Första kammarens protokoll, January 25, 1922, no. 4.

Västberg, Mauritz. 1924. Andra kammarens protokoll, March 12, 1924, no. 18.

Vennerström, Ivar. 1922. Andra kammarens protokoll, March 22, 1922, no. 21.

Vennerstöm, Ivar, Ernst Hage, and Carl Oscar Johansson. 1919a. Riksdag bill no. 326, "Angående första kammarens avskaffande och införande av enkammarsystem." Andra kammarens protokoll, February 19, 1919.

Vennerström, Ivar et al. 1919b. Riksdag bill no. 179, “Om en folkomröstning till utrönande av huruvida folket önskar den monarkiska statsförvaltningens bibehållande eller införande av republik." Andra kammarens protokoll, January 21, 1919.

Vennerström, Ivar et al. 1920. Riksdag bill no. 324, "Om utredning huru folkomröstningsinstitutet verkar i främmande länder." Andra kammarens protokoll, January 16, 1920.

von Geijer, Knut. 1920. Första kammarens protokoll, April 10, 1920, no. 32.

von Geijer, Knut. 1921. Första kammarens protokoll, May 4, 1921, no. 31.

von Geijer, Knut. 1922. Första kammarens protokoll, January 25, 1922, no. 4.

von Hofsten, Erland. 1920. Första kammarens protokoll, May 12, 1920, no. 46.

von Mentzer, Carl. 1919. Första kammarens protokoll, June 5, 1919, no. 53.

von Zweigbergk, Otto. 1919. Första kammarens protokoll, June 5, 1919, no. 53.

Werner, Alfred. 1920. Andra kammarens protokoll, May 12, 1920, no. 56.

Winberg, Carl. 1920. Första kammarens protokoll, April 10, 1920, no. 32.

Winberg, Carl. 1924a. Första kammarens protokoll, March 12, 1924, no. 19.

Winberg, Carl. 1924b. Första kammarens protokoll, April 9, 1924, no. 27. 
How to cite this article: Friberg, Anna. 2020. "History Politics and (Re)forming the Future: Visions of Democracy and the Category of the Utopian." Redescriptions: Political Thought, Conceptual History and Feminist Theory 23(1): 36-53. DOI: https://doi.org/10.33134/rds.326

Submitted: 30 August 2019 Accepted: 04 June 2020 Published: 13 July 2020

Copyright: ( 2020 The Author(s). This is an open-access article distributed under the terms of the Creative Commons Attribution 4.0 International License (CC-BY 4.0), which permits unrestricted use, distribution, and reproduction in any medium, provided the original author and source are credited. See http://creativecommons.org/licenses/by/4.0/.

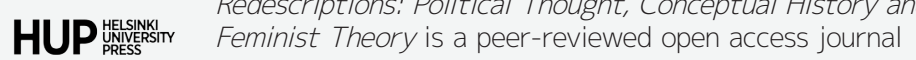
published by Helsinki University Press. 